\title{
Influence of Osmolality and Acidity on Fertilized Eggs and Larvae of Olive Flounder (Paralichthys olivaceus)
}

\author{
Ki-Hyuk Kim, Hye-Na Moon, Yun-Hye Noh, and ${ }^{\dagger}$ In-Kyu Yeo \\ Dept. of Marine Life Science, Jeju National University, Jeju 63243, Korea
}

Received: February 10, 2020

Revised: February 24, 2020

Accepted: February 28, 2020

${ }^{+}$Corresponding author

In-Kyu Yeo

Dept. of Marine Life Science, Jeju National

University, Jeju 63243, Korea.

Tel: +82-64-754-3474

Fax: +82-64-756-3493

E-mail: ikyeo99@jejunu.ac.kr

Copyright $\odot 2020$ The Korean Society of Developmental Biology.

This is an Open Access article distributed under the terms of the Creative Commons Attribution Non-Commercial License (http://creativecommons.org/licenses/ by-nc/4.0/) which permits unrestricted non-commercial use, distribution, and reproduction in any medium, provided the original work is properly cited.

ORCID

Ki-Hyuk Kim

https://orcid.org/0000-0003-4365-1607

Hye-Na Moon

https://orcid.org/0000-0002-1152-7532

Yun-Hye Noh

https://orcid.org/0000-0001-8838-3381

In-Kyu Yeo

https://orcid.org/0000-0002-7508-6967

\section{Conflict of interests}

The authors declare no potential conflict of interest.

\section{Acknowledgements}

This research was supported by Leading University Project for International Cooperation through the National Research Foundation of Korea (NRF) funded by the Ministry of Education (MOE) 2017 R1A2B4003441 and the 2019 scientific promotion program funded by Jeju National University.

Authors' contributions Conceptualization:Yeo IK.

\section{Abstract}

The $\mathrm{pH}$ of water is one of the main environmental factors exerting selective pressure on marine and freshwater organisms. Here, we focus on the influence of $\mathrm{pH}$ on an organism's ability to maintain homeostasis and investigate the effects of acidification on immunity-related genes and osmotic pressure during early development of the olive flounder, Paralichthys olivaceus. The aim of our study was to determine the influence of various $\mathrm{pH}$ levels on the fertilized eggs and larvae of $P$. olivaceus. Gametes of $P$. olivaceus were artificially introduced and the resulting fertilized eggs were incubated at pH 4.0 (low), 6.0, and 8.0 (equivalent to natural sea water; control). We found that all eggs sank from the water column at $\mathrm{pH}$ 4.0. After $38 \mathrm{~h}$, these eggs showed slow development. Hatching occurred more slowly at pH 4.0 and 6.0 and did not occur at all at pH 4.0. Result of gene expression, caspase and galectin-1 were expressed from the blastula to pre-hatch stages, with the exception of the two-cell stage. HSP 70 was also steadily expressed at all pH levels over the five days. The osmolality of fertilized eggs differed marginally at each stage and across $\mathrm{pH}$ levels. So, this results demonstrates that low $\mathrm{pH}$ level is detrimental to $P$. olivaceus fertilized eggs.

Keywords: Ion, $\mathrm{pH}$, Ocean acidification, Olive flounder (Paralichthys olivaceus), Osmolality

\section{INTRODUCTION}

Ocean acidification, caused by increasing atmospheric concentrations of $\mathrm{CO}_{2}$, is one of the most critical anthropogenic threats to marine life (Kim et al., 2015). The uptake of anthropogenic carbon dioxide $\left(\mathrm{CO}_{2}\right)$ by oceans has induced fundamental changes in seawater chemistry, which could have dramatic effects on ecosystems in the upper ocean (Gattuso and Hansson, 2011). Atmospheric $\mathrm{CO}_{2}$ diffuses passively at the ocean surface, forming carbonic acid, which dissociates into hydrogen and bicarbonate, and reduces $\mathrm{pH}$ (Fabry et al., 2008). In general, marine $\mathrm{pH}$ normally ranges from 7.8 to 8.2 (Knutzen et al., 1981) but increased dissolution of atmospheric $\mathrm{CO}_{2}$ has led to decreases in $\mathrm{pH}$. The $\mathrm{pH}$ of water is one of the main environmental factors exerting a selective pressure on marine and freshwater organisms, interfering with their ability to maintain homeostasis. As such, ocean acidification has become a central scientific issue in recent marine ecosystem research (Feely et al., 2009).

Osmolality and $\mathrm{pH}$ can have both direct and indirect effects on aquatic organisms. Cells of organisms can survive by actively preventing the absorption and release of minerals and by releasing some of the incoming minerals and reabsorption of drained water; this involves the expenditure of 
Data curation: Kim KH, Moon HN Formal analysis: Kim KH, Noh YH. Methodology: Yeo IK, Kim KH, Moon HN. Software: Kim KH, Moon HN, Noh YH. Validation: Yeo IK, Kim KH. Investigation: Kim KH, Moon HN. Writing - original draft:Yeo IK, Kim KH. Writing - review \& editing: Yeo IK, Kim KH.

\section{Ethics approval}

This article does not require IRB/IACUC approval because there are no human and animal participants. energy in the form of adenosine triphosphate (ATP). Alternatively, when the concentration of inorganic salts in the immediate environment is lower than that in body fluids, inorganic salts are released from the cell passively. Since the concentration of inorganic compounds in body fluids is not equal to their concentration in the surrounding water, energy is expended (in the form of ATP) to maintain homeostasis. Therefore, aquatic organisms are always regulating osmolality, either actively or passively.

Many studies have investigated the effects of $\mathrm{pH}$ variability on organisms in freshwater systems, where the environment can be subject to dramatic fluctuations. Numerous taxa, including trout, cichlids, and frogs, have shown osmotic and ionic imbalances as a result of acidic environments (Henriksen et al., 1984; Shu et al., 2015). Under projected climatic conditions, marine organisms may be subject to similar physiological pressures. Studies have shown that rainbow trout (Oncorbynchus mykiss), Atlantic salmon (Salmo salar), moor frog (Rana arvalis), and cichlid fish species are vulnerable to low $\mathrm{pH}$. In rainbow trout, ionic loss caused plasma osmotic pressure to fall precipitously at $\mathrm{pH} 4.2$ (Henriksen et al., 1984). In Atlantic salmon, rapid changes in $\mathrm{pH}$ and calcium and aluminum speciation may be a major reason for fish mortality (Henriksen et al., 1984). A study on moor frogs (Shu et al., 2015) showed that different ion channels and pumps were employed for embryonic survival under acid stress. In two cichlid fish species of the Amazon, discus fish were more tolerant to low $\mathrm{pH}$ than angelfish (Pterophyllum), as seen by the lesser effects of exposure to $\mathrm{pH} 3.6$ on unidirectional $\mathrm{Na}^{+}$uptake and efflux rates and net $\mathrm{Na}^{+}$and $\mathrm{Cl}^{-}$losses in the former species (Duarte et al., 2013). Although reductions in $\mathrm{pH}$ may negatively affect the survival, growth, reproduction, and physiological performance of marine organisms, variations in carbonate chemistry have detrimental effects on marine calcifiers, as the production of calcareous skeletal structures is hindered (Fabry et al., 2008). A study of orange clownfish (Amphiprion percula), revealed a decline in olfactory sensing capability under high $\mathrm{CO}_{2}$ conditions (Kim et al., 2015). Dixson et al. (2010) found that fish raised at higher $\mathrm{CO}_{2}$ levels could not easily escape from predators because they were not able to smell predators efficiently. Usually, fish larvae and eggs are more sensitive to $\mathrm{pH}$ changes than adult fish (Brown and Lynam, 1981) and the effects of ocean acidification are, therefore, more likely to be detected during these early life stages (Checkley et al., 2009). Previous studies have indicated that $\mathrm{pH}$ changes can induce serious ion deficiencies in seawater. While there are many studies of the effects of water acidification on freshwater fish species and amphibians, such studies are scarce in marine fishes.

In aquaculture facilities, water can become acidified due to nitrate and $\mathrm{CO}_{2}$ accumulation. Coastal areas and fish farms may also become acidified by nitrates from feed and drugs. The olive flounder (Paralichthys olivaceus) is a commercially important farmed fish species in China, Japan, and Korea with more than 43,000 tons cultured annually in Korean hatcheries, particularly on Jeju Island. In this study, we investigated the effects of $\mathrm{pH}$ on the spawning and hatching of $P$. olivaceus. We hypothesized that the fertilized eggs and larvae of $P$. olivaceus would be adversely affected under low $\mathrm{pH}$ conditions, particularly in terms of decreased osmotic pressure leading to high mortality and damage to fertilized eggs and larval skeletons. The innate immune response is fundamental defense response of vertebrates and invertebrates. Especially, the innate immune response important for larvae that lack of resistance to infectious in the early stages. Caspase, galectin-1, and HSP 70 are associated with immune function related to apoptosis, external mucous, and protection of impaired proteins, respectively. We assessed these hypotheses by examining ontogenic changes, osmolality, and expression of several immunity-related genes (caspase, galectin-1, and heat shock protein 70) in P. olivaceus eggs and larvae exposed to different $\mathrm{pH}$ levels. 


\section{MATERIALS AND METHODS}

\section{Seawater conditions}

Three different $\mathrm{pH}$ levels were used: 4.0, 6.0, and 8.0 (natural seawater, as a control) (salinity 35 $\mathrm{ppt}$ ). To attain each of these $\mathrm{pH}$ levels, approximately $10 \mathrm{~L}$ of natural seawater was passed through a filter flask and $\mathrm{pH}$ levels were adjusted using $\mathrm{HCl}$ or $\mathrm{NaCl}$. During the experiment, $\mathrm{pH}$ and salinity were calculated every $5 \mathrm{~h}$ using handheld $\mathrm{pH}$ meters (YSI 5909; YSI, Yellow Springs, OH, USA), which were calibrated daily, and levels were adjusted used $\mathrm{HCl}$ or $\mathrm{NaCl}$. Temperature and light were maintained at $19 \pm 0.5^{\circ} \mathrm{C}$ and $12 \mathrm{~h} \mathrm{light} / 12 \mathrm{~h}$ dark, respectively.

\section{Fertilized eggs}

Unfertilized eggs and semen of $P$. olivaceus were obtained from the National Institute of Fisheries Science (NIFS) in Wimi-Ri, Jeju, Korea. Adult mature P. olivaceus three males and four females were anesthetized in $100 \mathrm{ppm}$ of 2-phenoxyethanol. Semen and unfertilized eggs were collected by manual abdominal stripping at $20^{\circ} \mathrm{C}$ water temperature and $31.25 \pm 0.43$ salinity and were stored at $4^{\circ} \mathrm{C}$. To achieve artificial fertilization, the stripped eggs and semen were mixed dry and then the coelomic fluid was removed by washing the fertilized eggs with natural seawater three times in a bucket.

\section{Survival rate of eggs and larvae at various pH levels}

Two-liter beakers (three beakers per treatment for a total of nine) were seeded with 500 fertilized eggs. The overall survival rate in each was calculated, and embryonic development (over $38 \mathrm{~h}$ ) was monitored from zygotic cleavage to near-hatch readiness using an optical electron microscope (DE/ LMD07000; Leica Microsystems, Wetzlar, Germany). Ontogenic stages were defined, for all $\mathrm{pH}$ groups, as two-cell, four-cell, thirty-two-cell, morula, blastula, embryonic, heart differentiation, and pre-hatch stages. Survival rates of larvae were also calculated from the day of hatching for five days.

\section{Osmolality}

Osmolality was calculated for all $\mathrm{pH}$ treatments at the two-cell, blastula, embryonic, Kupffer's vesicle formation, and pre-hatch stages, and in post-hatch larvae for five days. Measurements were carried out using 20 fertilized eggs and 50 live larvae washed with Kimtech wipers in each beaker, washed three times with distilled water (DW) for each $\mathrm{pH}$ group, then homogenized and centrifuged at $15,000 \times \mathrm{g}$ at $4{ }^{\circ} \mathrm{C}$ for $10 \mathrm{~min}$. The osmolality of the supernatant was calculated from three measurements using a vapor pressure osmometer (Micro Osmometer 3300; Advanced Instruments, Norwood, MA, USA).

\section{Gene expression analysis}

Transcriptional gene expression levels were calculated from 10 fertilized eggs at the twocell, blastula, embryonic, Kupffer's vesicle formation, and pre-hatch stages, and five larvae were assessed on day 5. Total RNA was extracted using TRIzol (Life Technologies, Carlsbad, CA, USA) according to the manufacturer's instructions. One microgram of extracted RNA was treated with DNase I (Fermentas, Hanover, MD, USA) and used to synthesize cDNA using a Transcriptor First Strand cDNA Synthesis Kit (TaKaRa Bio, Kusatsu, Japan). Quantitative real time PCR was conducted using the TOPreal ${ }^{\mathrm{TM}}{ }_{\mathrm{qPCR}} \mathrm{2} \times$ PreMIX (SYBR Green with ROX, enzynomics). The primers for qPCR analysis of caspase, galectin-1, and heat shock protein-70 (HSP 70) genes in $P$. olivaceus were designed using the Primer 3 program (Ver. 0.4.0, http://frodo.wi.mit.edu/primer3; Table 1). PCR reactions were carried out at $95^{\circ} \mathrm{C}$ for $10 \mathrm{~min}$, followed by 45 cycles at $95^{\circ} \mathrm{C}$ for $10 \mathrm{~s}$, 
Table 1. Oligonucleotide primers used in this study

\begin{tabular}{cc}
\hline \hline Gene & Nucleotide sequence $\left(5^{\prime} \rightarrow 3^{\prime}\right)$ \\
\hline Caspase 3 F & TTACAACGCCCAGACAGTCGAGCA \\
Caspase 3 R & AGACACAAACTCTACCGCCACCTT \\
HSP 70F & CAAAGCGCACATTGTCTTCCAGCA \\
HSP 70R & CTCAAACTTGCCCAGCAGGTTGTT \\
Galectin 1 F & GAACATGTCCTTCAAGGTCGG \\
Galectin 1 R & CTCCTCACACCACTGTCTTCC \\
Beta actin F & TGAACCCTAAAGCCAACAGGGAGA \\
Beta actin R & TGATGCTGTTGTAGGTGGTCTCGT \\
\hline
\end{tabular}

$60^{\circ} \mathrm{C}$ for $15 \mathrm{~s}$, and $72^{\circ} \mathrm{C}$ for $30 \mathrm{~s}$, plus a final stage at $72^{\circ} \mathrm{C}$ for $30 \mathrm{~s}$.

\section{Statistical analysis}

All data were analyzed using a two-way ANOVA in IBM SPSS Statistics version 24.0 (IBM, 2017). Significance was assessed using Duncan's multiple range test, and statistical significance was assumed at $p<0.05$.

\section{RESULTS}

\section{1. pH levels during embryogenesis}

There were no differences in eggs among treatments from the beginning of hatching to $30 \mathrm{~h}$ (embryonic stage). We found that each head part varied in size among treatments at the heart differentiation stage and 1-5 days post-hatching (Fig. 1). After 38 h, fertilized eggs showed differences in head size. We observed larger head sizes in the $\mathrm{pH} 6.0$ treatment than $\mathrm{pH} 4.0$ and 8.0 levels. There was no evidence of differences in morphology across zygotes reared in different $\mathrm{pH}$ environments until the embryonic stage. However, zygotes at $\mathrm{pH} 4.0$ developed considerably more slowly than those at $\mathrm{pH} 6.0$ and 8.0 levels (Fig. 2). After 38 h, all embryos in the $\mathrm{pH} 4.0$ treatment either sank or failed to hatch, yielding a mortality rate of 100\%; mortality for $\mathrm{pH} 6.0$ and 8.0 levels ranged from $66.5 \%$ to $69.4 \%$ (Table 2). And no significant differences in morphology were seen from the two-cell stage until the blastula stage.

\section{Survival rate and morphology of larvae}

Hatching occurred more slowly at pH 4.0 and 6.0 (38 h vs. 30 h; Fig. 1) and did not occur at all at $\mathrm{pH} 4.0$ (Table 2). The mortality rates of larvae at $\mathrm{pH} 6.0$ and 8.0 were $8.43 \%$ and $6.44 \%$, respectively (Table 3).

\section{Caspase, galectin-1, and HSP $\mathbf{7 0}$ expression in P. olivaceus larvae}

Expression profiles showed that all three genes were expressed at all $\mathrm{pH}$ levels (Fig. 3). Caspase and galectin-1 were expressed from the blastula to pre-hatch stages, with the exception of the two-cell stage. Caspase was much more strongly expressed at $\mathrm{pH} 4.0$ and 6.0 than at $\mathrm{pH}$ 8.0. This expression increased over time in developing embryos at $\mathrm{pH}$ 6.0. Galectin-1 was continuously expressed at the pre-hatch stage, but expression decreased with time. HSP 70 was also expressed at all $\mathrm{pH}$ levels after the two-cell stage. In particular, HSP 70 expression was similar from the blastula stage until the pre-hatch stage. Post-hatch, beta actin was expressed at all $\mathrm{pH}$ levels (Fig. 4). HSP 
A Full length

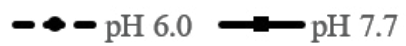

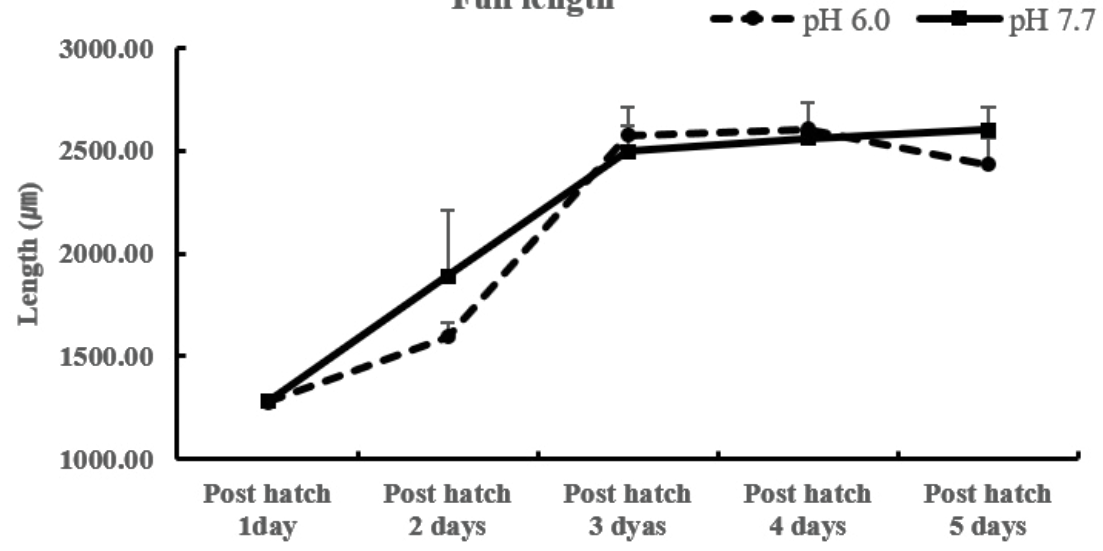

B Head length

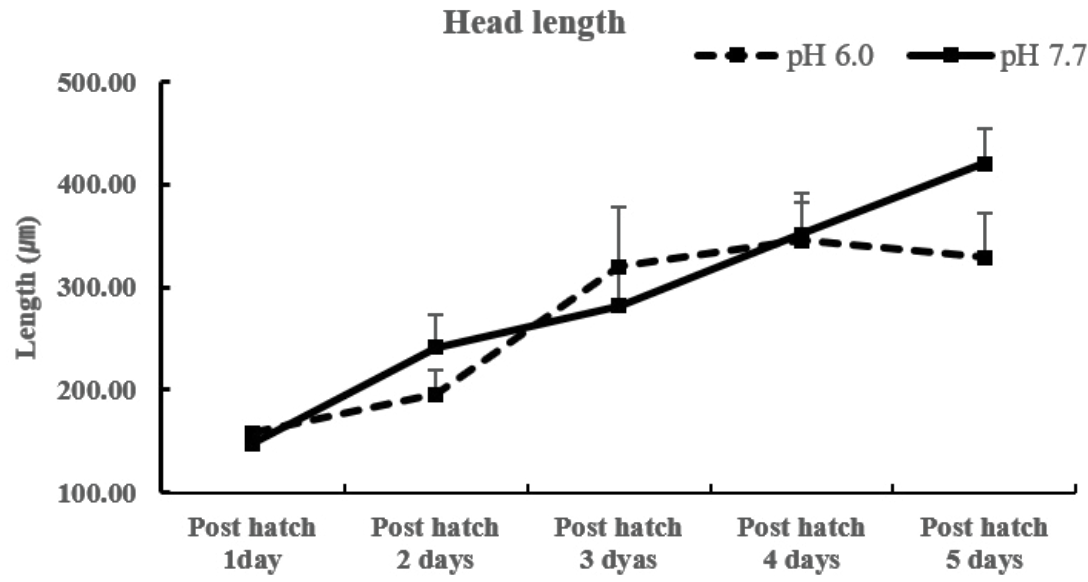

C

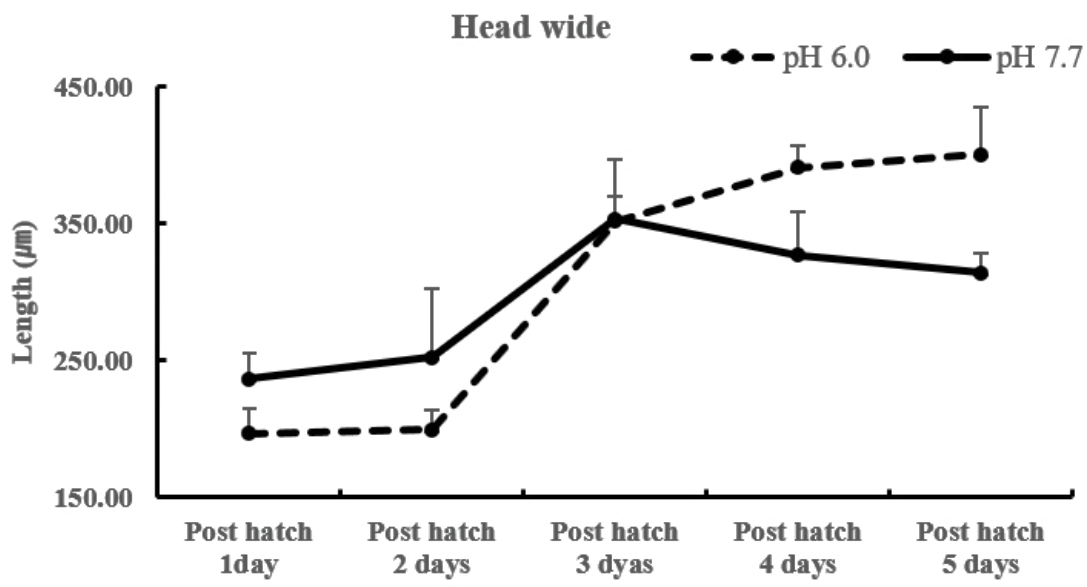

Fig. 1. Full length, head length and head wide of effect on $\mathrm{pH}$ exchange. 


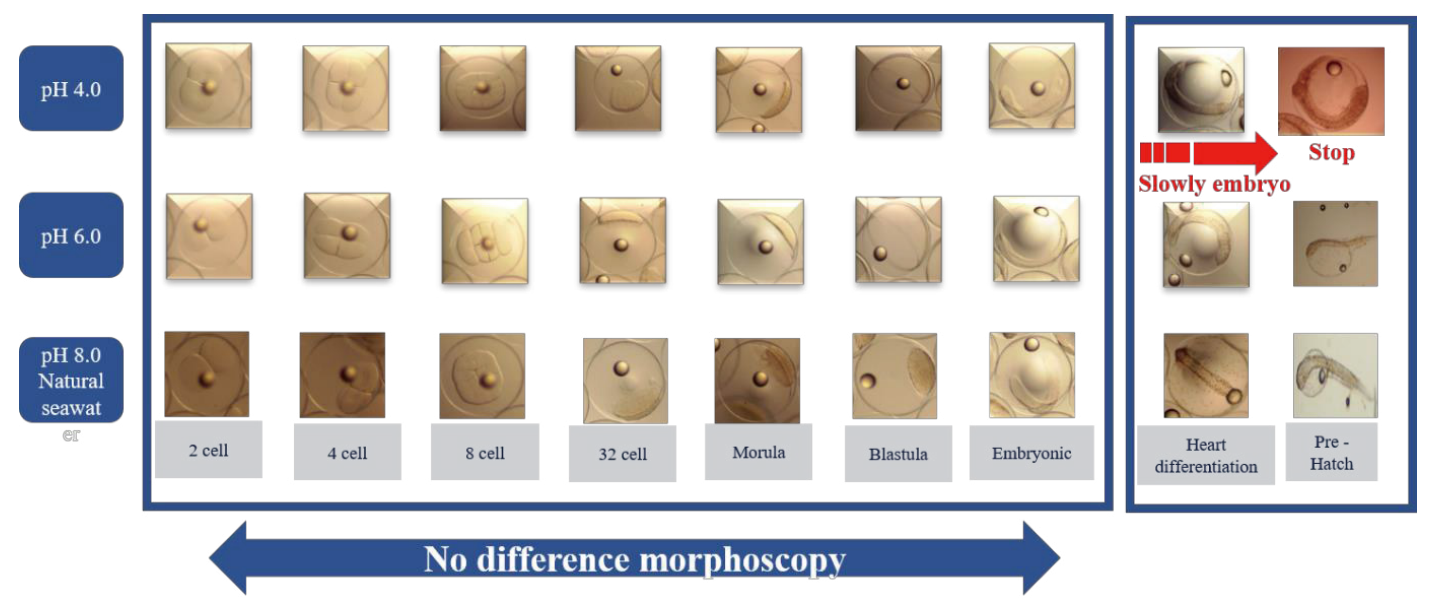

Fig. 2. The morphoscopy of fertilized eggs.

70 was also steadily expressed at all $\mathrm{pH}$ levels over the five days. However, caspase and galectin-1 were not expressed at $\mathrm{pH} 8.0$ post hatch.

\section{Osmolality results}

The osmolality of fertilized eggs was below $200 \mathrm{mmol} / \mathrm{kg}$, which was maintained until after the embryonic stage in all $\mathrm{pH}$ groups (Fig. 5A). At the pre-hatch stage, osmolality was not significant but at the Kupffer's vesicle formation stage it was significant in all $\mathrm{pH}$ groups. Osmolality increased from the two-cell stage until the blastula stage but was unchanged between the embryonic and prehatch stages. At later stages, osmolality increased considerably. Two days after hatching, osmolality was significantly higher at $\mathrm{pH} 8.0$ (natural seawater), but there was no significant difference in osmolality between the other $\mathrm{pH}$ groups (Fig. 5B).

\section{DISCUSSION}

Our investigation of morphology, hatch rate, osmolality and gene expression at different $\mathrm{pH}$ levels revealed that an acidic environment harms the development of the fertilized eggs and larvae of $P$. olivaceus. At $\mathrm{pH} 4.0$, eggs showed delayed differentiation and eventually sank to the bottom.

Table 2. The rate of demersal eggs in Olive flounder, Paralichthys olivaceus

\begin{tabular}{ccc}
\hline \hline $\mathrm{pH}$ section & Number of demersal eggs & Percentage (\%) \\
\hline $\mathrm{pH} 4.0$ & $500 \pm 0.00$ & 100 \\
$\mathrm{pH} 6.0$ & $167.67 \pm 30$ & 33.5 \\
$\mathrm{pH} 8.0$ & $153.00 \pm 46$ & 30.6 \\
\hline
\end{tabular}

Table 3. The mortality of larvae after hatched in Olive flounder, Paralichthys olivaceus

\begin{tabular}{cccccc}
\hline \hline pH section & 1 day & 2 days & 3 days & Number of deaths & Death rate $(\%)$ \\
\hline $\mathrm{pH} 4.0$ & 0 & 0 & 0 & 0 & 0 \\
$\mathrm{pH} 6.0$ & $4.00 \pm 2$ & $8.33 \pm 9$ & $15.67 \pm 7$ & $28.00 \pm 14$ & 8.43 \\
$\mathrm{pH} 8.0$ & $7.33 \pm 4$ & $7.67 \pm 3$ & $7.33 \pm 6$ & $22.33 \pm 0.58$ & 6.44 \\
\hline
\end{tabular}


A

pH 4.0 Gene expression

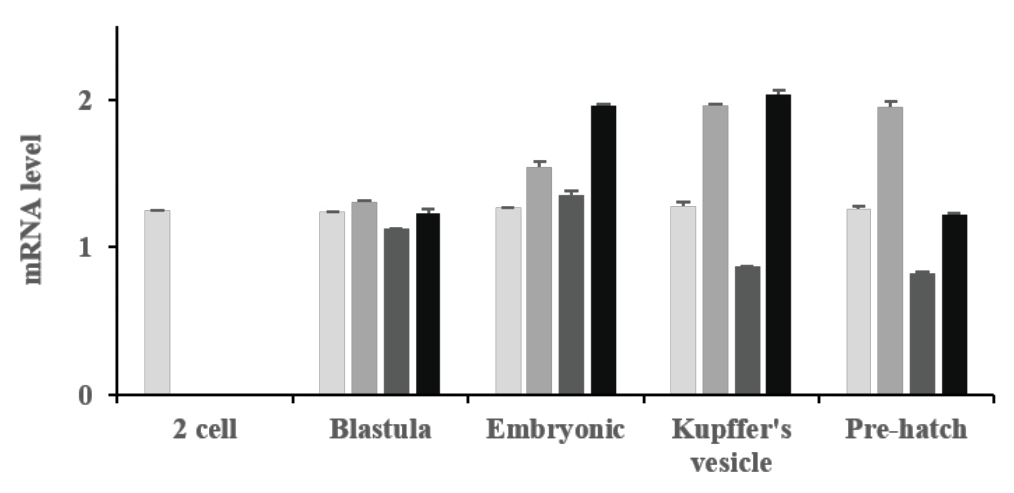

$\square$ Beta actin $\square$ Caspase $\square$ Galectin-1 $\quad$ HSP 70

B pH 6.0 Gene expression

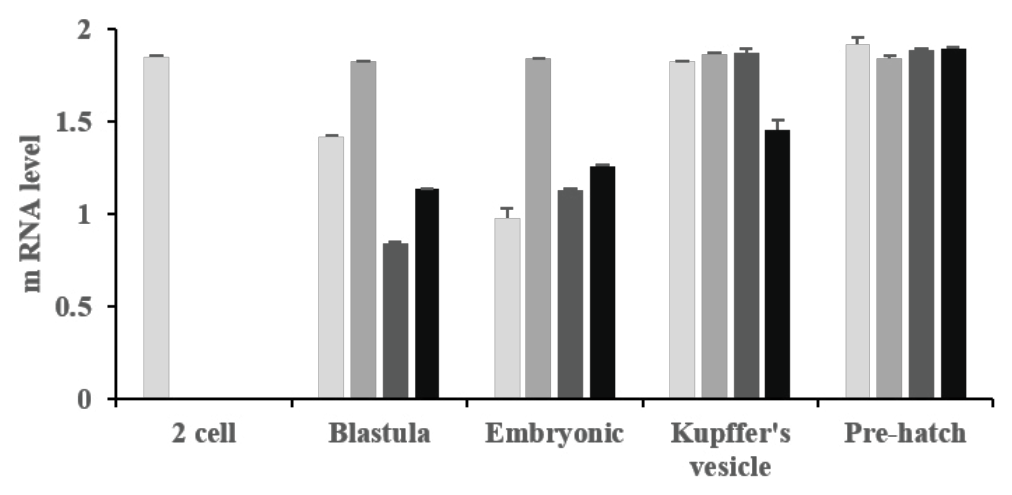

$\square$ Beta actin $\square$ Caspase $\square$ Galectin-1 $\quad$ HSP 70

C pH 8.0 Gene expression

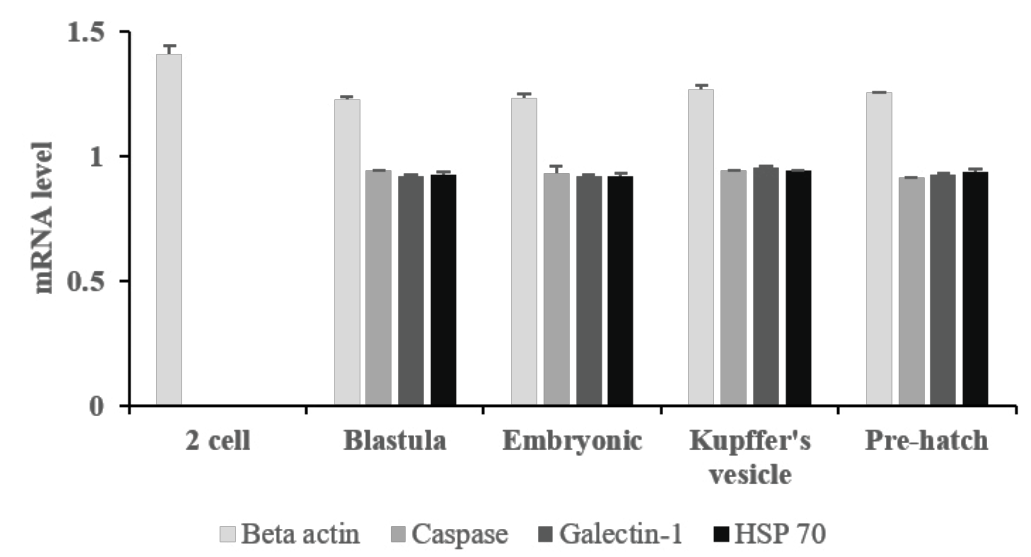

Fig. 3. Gene expression of Olive flounder, Paralichthys olivaceus, immune related genes among in various stage of fertilized eggs. 


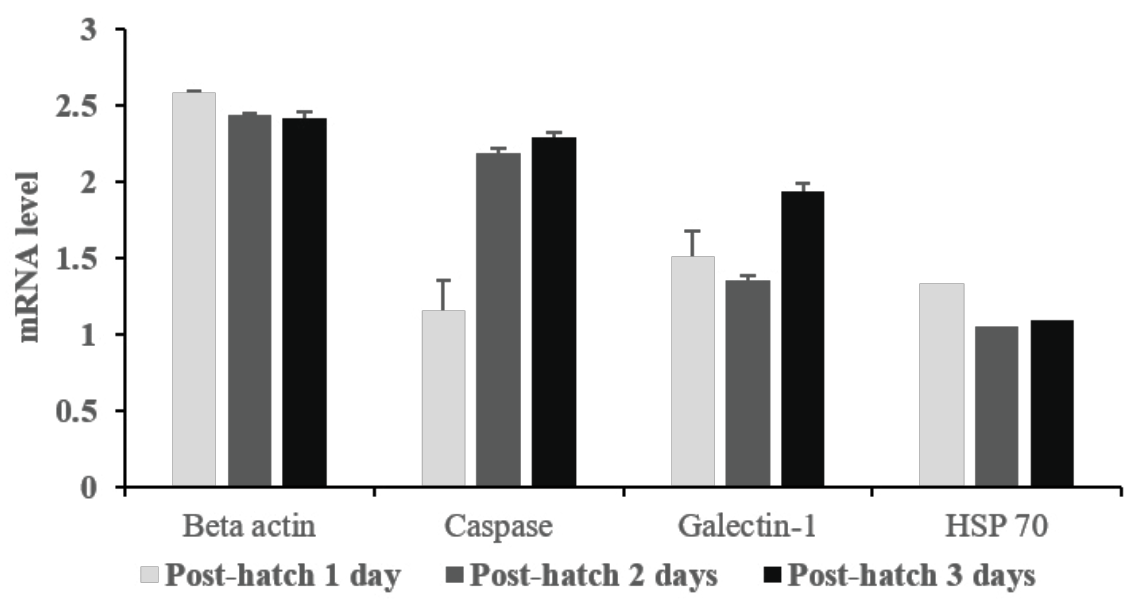

B

pH 8.0 Gene expression

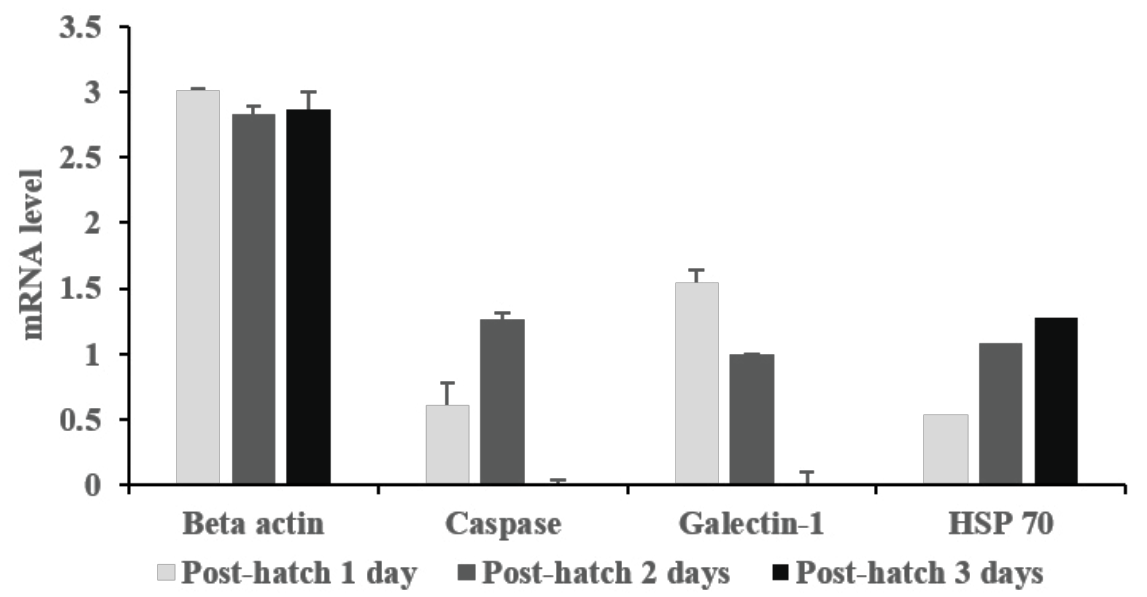

Fig. 4. Gene expression of Olive flounder, Paralichthys olivaceus, immune related genes among in various stage of pro-hatch.

Generally, the hatching enzyme (chorionase or envelysin) is secreted by the integument of the snout (Bell et al., 1969) to digest much of the zona radiata (Peterson et al., 1980). Many studies have reported hatch failure or slow growth of fertilized eggs at low $\mathrm{pH}$. The hatching delay described above was observed at low $\mathrm{pH}$ and is similar to the results of previous studies (Daye and Garside, 1980). In contrast, Trojnar reported that hatching of brook trout eggs reared at low $\mathrm{pH}$ was more rapid than at higher $\mathrm{pH}$ values (Trojnar et al., 1977). In Atlantic salmon, hatching of eggs in acidic water was delayed by six days at $\mathrm{pH} 4.5-5.0$, and did not occur at all at $\mathrm{pH} 4.0$ to 4.2 (Peterson et al., 1980). We hypothesize that low $\mathrm{pH}$ can affect hatching enzyme secretion. We also found that both acidification and alkalinization of water affected spawning and led to increased egg mortality at levels comparable to those found in other marine and freshwater species, as demonstrated by similar mortality rates seen at $\mathrm{pH} 6.0$ and 8.0 (Henriksen et al., 1984). Generally, the osmolalities of seawater and freshwater are in contrast with each other. Osmolality at $\mathrm{pH} 4.0$ was not significantly different from that at $\mathrm{pH} 6.0$ and 8.0, except at the Kupffer's stage. This is assumed to be due to the formation of chloride cells at this stage. Acute exposure to acidified water results in a fall in the osmotic value of the blood: the lower the $\mathrm{pH}$ of water. In this study, an electron micrograph of a 
A

$\square \mathrm{pH} 4.0 \quad \square \mathrm{pH} 6.0 \quad \square \mathrm{pH} 8.0$

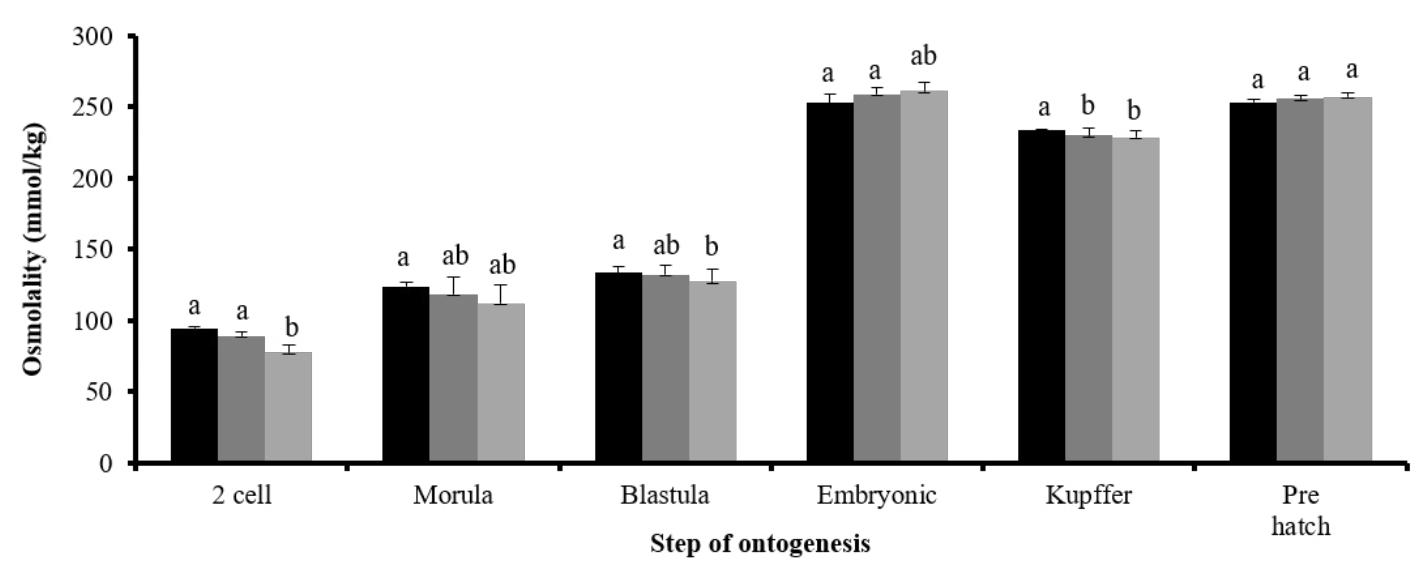

B

$\square \mathrm{pH} 6.0 \quad \square \mathrm{pH} 8.0$

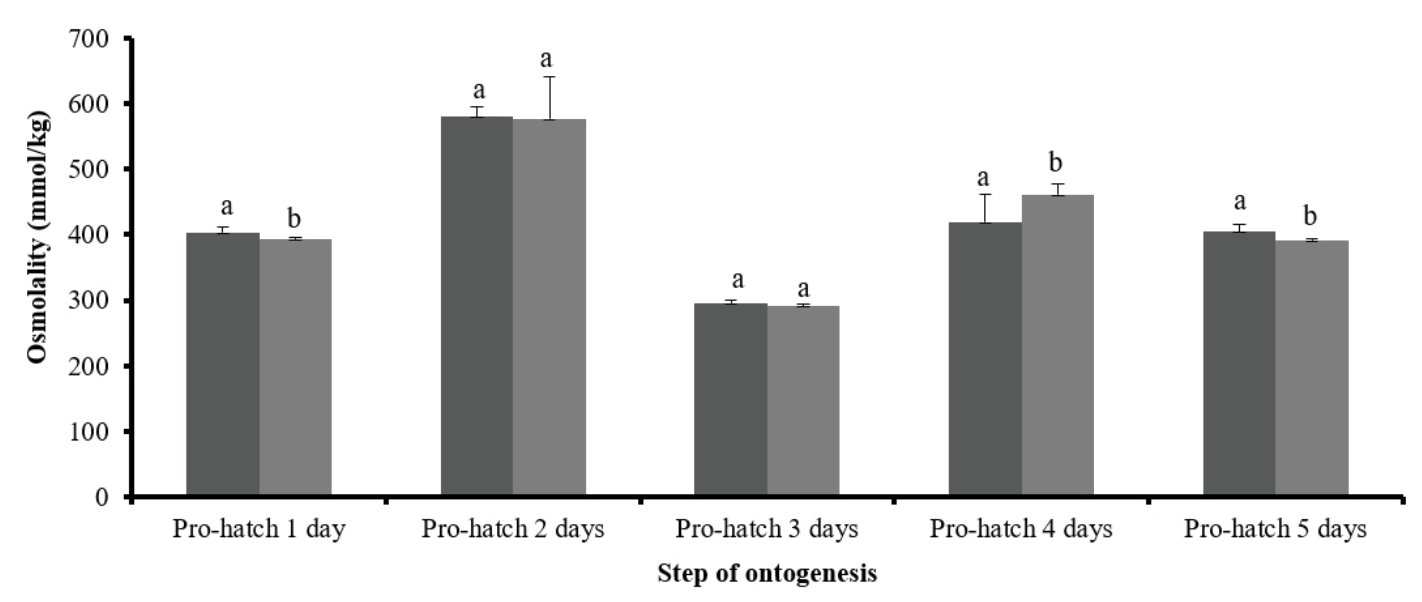

Fig. 5. The osmolality of Olive flounder, Paralichthys olivaceus, ontogeny and hatch stage. (A) Fertilized eggs stage osmolality, (B) Hatch days. ${ }^{\text {a,b }}$ means with different letters are significantly different $(p<0.05)$.

chloride cell exposed to acidified water showed that the tubes of the tubular system were swollen, a sign of early aging of the cell, probably caused by the low $\mathrm{pH}$. At two days post hatching, osmolality had increased for all $\mathrm{pH}$ treatments and was not significantly different between $\mathrm{pH} 6.0$ and 8.0. With sublethal water acidification, the osmotic value often remains very low for weeks, as has been observed with many species of trout and goldfish (Bonga and Dederen, 1986).

Numerous studies have investigated fish behavior in relation to a wide variety of environmental factors, but information on the effects of $\mathrm{pH}$ on fish behavior is sparse (Scott et al., 2005). We observed that the head size of developing embryos was affected by $\mathrm{pH}$, with embryos developing at $\mathrm{pH} 6.0$ having larger head size, however, this effect was not evident at $\mathrm{pH} 4.0$. Survival rates in natural seawater were higher (Table 2 and Fig. 1) at both the fertilized egg and larval stages, and so differences in growth and ontogeny were assumed to be related to low $\mathrm{pH}$. At $38 \mathrm{~h}$, eggs at $\mathrm{pH} 6.0$ and 8.0 hatched (Fig. 2); all eggs at $\mathrm{pH} 4.0$ sank out of the water column. Fluctuating $\mathrm{pH}, \mathrm{Ca}$ ion, and Al levels in water can be lethal to fish (Henriksen, 1984). Carline et al. (1992) reported that radio-tracked brook trout (Salvelinus fontinalis) migrated downstream in response to acid runoff, though it is unclear whether this response was due to elevated aluminum or low $\mathrm{pH}$ (Carline et al., 
1992). We assume that mortality in $P$. olivaceus eggs was induced by low $\mathrm{pH}$ and related to a lower $\mathrm{Ca}$ ion concentration.

Generally, the exposure of the skin to acid makes it more susceptible to disease (McDonald, 1983; McWilliams and Potts, 1978). Of the genes we investigated, we found that the expression of caspase, which is associated with apoptosis, was highest at $\mathrm{pH} 4.0$ and 6.0 (Fig. 3 and 4). Its expression increased with time, suggesting that it may hamper embryonic development. Caspase was also highly expressed at $\mathrm{pH}$ 8.0. Hence, we assume that it is more related to growth at low than at high $\mathrm{pH}$. Galcetin-1 is related to mucus production in the skin and was more highly expressed at $\mathrm{pH} 6.0$ than at $\mathrm{pH}$ 4.0. Its expression was more uniform in $\mathrm{pH} 6.0$ and 8.0 at the pre-hatch stage. At this stage, thinning of membranes by increased ion exchange is assumed to occur. Galectin-1 is primarily involved in skin barrier function and is expressed in digestive tissues against pathogen infection. The digestive tract developmental period is important for protection against pathogen invasion and galectin-1 can aid in this aspect as well (Jang et al., 2013). Galectin-1 expression levels decreased with time at most $\mathrm{pH}$ levels, but it was continuously expressed at $\mathrm{pH}$ 6.0. Meanwhile, HSP 70 is known to be an important part of the cell machinery for protein folding, and helps to protect cells from stress. This gene was expressed at all $\mathrm{pH}$ levels at both the fertilized egg and larval stages. Its expression decreased with time at $\mathrm{pH} 6.0$, but increased with time at the larval stage at $\mathrm{pH} 8.0$ (Fig. 4). This suggests a possible deleterious effect of low $\mathrm{pH}$ on the stable expression of the galectin- 1 and HSP 70 genes.

The observed effects on osmolality are unusual in marine fishes, which may offer insight into the evolution of osmolality and ionoregulation (Shartau et al., 2017). Generally, fish osmolality is approximately $300 \mathrm{mmol} / \mathrm{kg}$ and is controlled by chloride cells and the yolk sac in fertilized eggs and gills through $\mathrm{Na}^{+} / \mathrm{K}^{+}$ATPase. Here, osmolality was below $200 \mathrm{mmol} / \mathrm{kg}$ until the embryonic stage and $>200$ afterward, at all $\mathrm{pH}$ levels (until the pre-hatch stage). Osmolality in acid-stressed rainbow trout was under $300 \mathrm{mmol} / \mathrm{kg}$ (Lee et al., 1983), which is consistent with our results. Therefore, we speculate that osmolality is related to the chloride cells and yolk sacs of fertilized eggs. Ion homeostasis in freshwater fish is achieved using specialized branchial transport mechanisms for active ion uptake from environments that are hypotonic to the blood, plus a tight gill epithelium to minimize ionic diffusive losses (Evans., 2011; Hwang et al., 2011). Generally, gill epithelia are considered to be the major sites of ion regulation in both freshwater and marine teleosts, with up to $90 \%$ of all acid-base transport achieved in these tissues (Heisler, 1986). Common to these mechanisms for $\mathrm{Na}^{+}$uptake is $\mathrm{Na}^{+} / \mathrm{K}^{+}$ATPase (NKA) in the basolateral membrane of gill ionocytes, which exports $\mathrm{Na}^{+}$into the blood and contributes to the electrochemical gradient that drives $\mathrm{Na}^{+}$ uptake across the apical membrane (Hwang et al., 2011). The osmolality of fish at the pre-hatch stage was not notable, however, two days after hatching, at all $\mathrm{pH}$ levels, osmolality was higher than at any other point in time. The reasons for this are unclear and require further investigation into ion exchange. Low $\mathrm{pH}$-induced fish or egg mortality may result from ion transport defects in $\mathrm{Na}^{+}$/ $\mathrm{K}^{+}$ATPase, which cause reduced osmotic pressure (Bonga and Dederen, 1986). Furthermore, low $\mathrm{pH}$ stimulates appetite and dietary intake of larvae because they must actively excrete excess ions to maintain their osmotic balance (Kim et al., 2015). Marine fish constantly counteract osmotic water loss to their hyperosmotic environment by drinking, i.e., absorbing salt and water across the gastrointestinal tract, and actively secreting the surplus salt load at the gills (Michael et al., 2016). Chloride ions enter via the $\mathrm{Na}^{+}$gradient provided by $\mathrm{Na}^{+} / \mathrm{K}^{+}$ATPase and are secreted at the apical membrane through CFTR-type (cystic fibrosis transmembrane conductance regulator) ion channels. $\mathrm{Na}^{+}$ions flow passively through paracellular tight junction pathways (Evans et al., 2005; Hwang et al., 2011; Michael et al., 2016). Osmoregulators maintain a relatively constant internal osmotic pressure over a range of environmental salinities (Foshtomi et al., 2007). It is 
assumed that salinity and $\mathrm{pH}$ are correlated. A study of moor frogs revealed that ion channels and pumps are responsible for ion flux in cells, and are key mechanisms mediating cellular function. The resulting ion flux can mediate adaptive divergence of natural populations at early life stages in the face of environmental stress (Shu et al., 2015). Notably, two days after hatching, osmolality was significantly higher at $\mathrm{pH} 8.0$ than at $\mathrm{pH} 4.0$ and 6.0, and the difference was significant (except at three days post hatching). We hypothesize that changes in morphology, hatch rate, osmolality, immunity-associated gene expression, and growth rates of $P$. olivaceus eggs and larvae at low $\mathrm{pH}$ are connected to an ion-regulation defect. So, this results demonstrates that low $\mathrm{pH}$ level is detrimental to $P$. olivaceus fertilized eggs.

\section{CONCLUSION}

Many studies have examined the effects of acidification on freshwater fish species, however, there are fewer reports for marine fishes. In this study, we investigated the effects of acidic environments on P. olivaceus eggs and larvae and our results are similar to those from most corresponding freshwater fish studies. Therefore, further studies on marine fish species should be designed based on previous studies of similar effects in freshwater species. $\mathrm{pH}$ is one of the main environmental factors affecting aquatic organisms, along with salinity and water temperature. The observed effects on P. olivaceus eggs and larvae at low $\mathrm{pH}$ are assumed to be connected to ion-regulation. Future research should investigate how ion exchange is carried out by yolk sacs and chloride cells in the fertilized eggs and larvae of $P$. olivaceus, and calcium requirements and feeding capacity under low $\mathrm{pH}$ conditions.

\section{REFERENCES}

Bell MA, Foster SA (1994) Introduction to the evolutionary biology of the threespine stickleback. In: Bell MA, Foster SA (eds), The Evolutionary Biology of the Threespine Stickleback. Oxford University Press, Oxford, UK, pp 1-27.

Bonga SEW, Dederen LHT, (1986) Effects of acidified water on fish. Endeavour 10:198-202.

Brown DJA, Lynam S (1981) The effect of sodium and calcium concentrations on the hatching of eggs and the survival of the yolk sac fry of brown trout, Salmo trutta L. at low pH.J Fish Biol 19:205-211.

Carline RF, DeWalle DR, Sharpe WE, Dempsey BA, Gagen CJ, Swistock B (1992) Water chemistry and fish community responses to episodic stream acidification in Pennsylvania, USA. Environ Pollut 78:45-48.

Checkley DM, Dickson AG, Takahashi M, Radich JA, Eisenkolb N, Asch R (2009) Elevated $\mathrm{CO}_{2}$ enhances otolith growth in young fish. Science 324:1683.

Daye PG, Garside ET (1980) Structural alterations in embryos and alevins of the Atlantic salmon, Salmo salar L., induced by continuous or short-term exposure to acidic levels of $\mathrm{pH}$. Can J Zool 58:27-43.

Dixson DL, Munday PL, Jones GP (2010) Ocean acidification disrupts the innate ability of fish to detect predator olfactory cues. Ecol Lett 13:68-75.

Duarte RM, Ferreira MS, Wood CM, Val AL (2013) Effect of low $\mathrm{pH}$ exposure on $\mathrm{Na}^{+}$regulation in two cichlid fish species of the Amazon. Comp Biochem Physiol Part A: Mol Integr Physiol 166:441-448.

Evans DH, Piermarini PM, Choe KP (2005) The multifunctional fish gill: Dominant site of gas exchange, osmoregulation, acid-base regulation, and excretion of nitrogenous waste. Physiol 
Rev 85:97-177.

Evans DH (2011) Freshwater fish gill ion transport: August Krogh to morpholinos and microprobes. Acta Physiol 202:349-359.

Fabry VJ (2008) Marine calcifiers in a high- $\mathrm{CO}_{2}$ ocean. Science 23:1020-1022.

Fabry VJ, Seibel BA, Feely RA, Orr JC (2008) Impacts of ocean acidification on marine fauna and ecosystem processes. ICES J Mar Sci 65:414-432.

Feely RA, Doney SC, Cooley SR (2009) Ocean acidification: Present conditions and future changes in a high- $\mathrm{CO}_{2}$ world. Oceanography 22:36-47.

Foshtomi MY, Abtahi B, Sari AE, Taheri M (2007) Ion composition and osmolarity of Caspian Sea ctenophore, Mnemiopsis leidyi, in different salinities.J Exp Mar Biol Ecol 352:28-34.

Gattuso JP, Hansson L (2011) Ocean acidification: Background and history. In: Jean-Pierre G, Lina H (eds), Ocean Acidification. Oxford University Press, Oxford, UK, pp 1-20.

Heisler N (1986) Acid-Base Regulation in Animals. Elsevier, New York, NY.

Henriksen A, Skogheim OK, Rosseland BO (1984) Episodic changes in $\mathrm{pH}$ and aluminiumspeciation kill fish in a Norwegian salmon river. Vatten 40:255-260.

Hwang PP, Lee TH, Lin LY (2011) Ion regulation in fish gills: Recent progress in the cellular and molecular mechanisms. Am J Physiol Regul Integr Comp Physiol 301:R28-R47.

Jang MS, Lee YM, Yang H, Lee JH, Noh JK, Kim HC, Park CJ, Park JW, Hwang IJ, Kim SY (2013) Gene analysis of galectin-1, innate immune response gene, in olive flounder Paralichthys olivaceus at different developmental stage.J Fish Pathol 26:255-263.

Kim KS, Shim JH, Kim S (2015) Effects of $\mathrm{CO}_{2}$-induced ocean acidification on the growth of the larval olive flounder Paralichthys olivaceus. Ocean Sci J 50:381-388.

Knutzen J (1981) Effects of decreased pH on marine organisms. Mar Pollut Bull 12:25-29.

Lee RM, Gerking SD, Jezierska B (1983) Electrolyte balance and energy mobilization in acidstressed rainbow trout, Salmo gairdneri, and their relation to reproductive success. Environ Biol Fish 8:115-123.

Michael K, Kreiss CM, Hu MY, Koschnick N, Bickmeyer U, Dupont S, Lucassen M (2016) Adjustments of molecular key components of branchial ion and $\mathrm{pH}$ regulation in Atlantic cod (Gadus morhua) in response to ocean acidification and warming. Comp Biochem Physiol B Biochem Mol Biol 193:33-46.

McDonald DG (1983) The effects of $\mathrm{H}^{+}$upon the gills of freshwater fish. Can J Zool 61:691-703.

McWilliams PG, Potts WTW (1978) The effects of $\mathrm{pH}$ and calcium concentrations on gill potentials in the brown trout, Salmo trutta. J Comp Physiol B Biochem Syst Environ Physiol 126:277-286.

Peterson RH, Daye PG, Metcalfe JL (1980) Inhibition of Atlantic salmon (Salmo salar) hatching at low $\mathrm{pH}$. Can J Fish Aqua Sci 37:770-774.

Scott DM, Lucas MC, Wilson RW (2005) The effect of high $\mathrm{pH}$ on ion balance, nitrogen excretion and behaviour in freshwater fish from an eutrophic lake: A laboratory and field study. Aquat Toxicol 73:31-43.

Shartau RB, Brix KV, Brauner CJ (2017) Characterization of $\mathrm{Na}^{+}$transport to gain insight into the mechanism of acid-base and ion regulation in white sturgeon (Acipenser transmontanus). Comp Biochem Physiol A Mol Integr Physiol 204:197-204.

Shu L, Laurila A, Räsänen K, (2015) Acid stress mediated adaptive divergence in ion channel function during embryogenesis in Rana arvalis. Sci Rep 5:14201.

Tseng YC, Hu MY, Stumpp M, Lin LY, Melzner F, Hwang PP (2013) $\mathrm{CO}_{2}$-driven seawater acidification differentially affects development and molecular plasticity along life history of fish (Oryzias latipes). Comp Biochem Physiol A Mol Integr Physiol 165:119-130. 